\title{
Reconsidering the influence of Islam on Yoruba cultural heritage, 1930-1987
}

\author{
Akeem Abiodun Oladiti \\ Ladoke Akintola University of Technology, Nigeria
}

\section{Introduction}

In the words of Fafunwa, Islamic literacy in Yoruba land had been an important factor that had contributed to the growth and development of Islam in Nigeria (Fafunwa, 1974, p. 42). According to Fafunwa, Islamic education had established firm roots long before the arrival of western education popularized by the Christian missionaries in the 1840's (Ajayi, 1965, p. 5). Among seven Yoruba speaking communities in Nigeria. Five have a considerable influence of Islam on Yoruba culture historically. This is evident in the point that a significant percentage of the population found in Oyo, Ogun, Osun, Lagos, Kwara are predominantly Muslims unlike in Ondo and Ekiti state (Gbadamosi, 1978, p. 77). Indeed, Islam as a religion has played a major role in shaping Yoruba culture and education in West Africa (Trimingham, 1969, p. 62). However, as Akinola (Akinola, 1995, p. 1) observes, "the real essence and impact of Islamic activities in Africa have not been contextualized by historians and is long overdue". This paper is thus motivated by this gap. A new approach has therefore been used in this paper to explain how Islam has affected Yoruba culture.

By the second half of the 19th century, Islam had been a factor that could not be dissociated from the social, political and educational life of the Yoruba people. Thus, Fajana describes Islamic literacy as cheap and within the reach and understanding of peasant farmers. It is basically a religious duty that should be preserved and nurtured with no expectation of financial reward. This noble principle was introduced at the early stage of the development of Islam in Yoruba society (Fajana, 1978, p 11). 


\section{Islamic Literacy and Cultural Influence}

With the introduction of Islam to Yoruba society in the 18th century, Islamic literacy had considerably attracted the attention of the Muslims to improve and practice Islamic religious activities (Mahmud, 1983, p. 37). According to Raheemson, Arabic schools were established to reduce the conversion of Muslim children to Christianity by the missionaries during the colonial period. Arabic which is regarded as the language of Islam has been used as a vehicle of keeping and preserving African historical records which Yoruba Muslims can proudly call their own is expressed in Arabic writing (Raheemson, 1988, p. 18).

Arabic writing was the only channel of communication expressed in writing form for business or commercial purposes, diplomatic correspondence and writing of letters. Most of the available writing documents by the Yoruba Muslim teachers were found in Arabic. These to a greater extent formed valuable source materials for the reconstruction of the history of the Yoruba Muslim communities. For instance, Sheikh Adam Abdullah Al-llory (1912-1992) a prominent Yoruba Muslim teacher and preacher in Lagos wrote several books $n$ Arabic language that has enriched the knowledge of the growth of Islam among Yoruba Muslims and which up till today have been found useful by modern African historians in the documentation and reconstruction of the history of the Yoruba Muslims in Nigeria (Hunwick, 1997, p. 210). Some of such works include: Al islam fi njiriiya wa uthman ibn fodi, Tarikh - al - dawah - al - islamiyyah, Mashakil - al - ta - lim Arabi fi nijiriyya and Lamahat al balhur nasim al-saba fi akbarul islam wa ulama bilad yuruba. The English meaning of the text writing above are "A History of Islam in Nigeria after Uthman Dan Fodio", "History of Preaching of Islam, "Problems of Arabic Teaching in Nigeria", and "Islam and Muslim scholars in Yoruba land".

Islamic literacy has helped the Yoruba communities to develop systematic and specialized means of writing and documentation to aid memory. His point attest to the fact that Arabic was the first and only form of writing culture before the coming of Europeans in the 19th century. This shows that Islamic religion through its literacy in Arabic promotes a remarkable height of scientific achievement and scholarship that is impressive and influential to Yoruba social thought (Mahmud, 1983, p. 37). 
For the Muslims throughout the Yoruba land, the Qur'an represents the highest linguistic achievement of the Arabic language. For this reason, it has become a factor to be considered in any study of the Arabic language. This conviction facilitated the rapid development and dissemination of Arabic and also contributed immensely to its transformation, from an obscure dialect, into one of the important languages of medieval and modern times. The relationship between Arabic with Islamic religion has been described by Browne in the following words:

The Arabic language is in special degree the language of a great religion. To us the Bible is the Bible, whether we read it in the original tongues or in our own, but it is otherwise with the Qur'an amongst the Muslims. To them this Arabic Qur'an is the very word of God, an objective, not a subjective revelation (Brown, 1975, p. 91).

The above submission shows that the Qur'an is held by the Muslims to be the very word of God that was revealed to Muhammed in the Arabic language. Thus, it is a religious duty to learn the Arabic language because it is the language of Qur'an, which is the major sacred literature of the Muslims, irrespective of colour, race or nationality. P.K. Hitti confirms thus:

The classical form is not the literary form used by the Arabic writing. Pleases (sic) out also the religion language of all Muslims, no matter their native tongue may be. To Muslims, Arabic is the only appropriate language to approach Allah (Hitti, 1982, p. 112).

Mahmud Manzur, claims that it is God who made the Arabic language superior to all other languages and he enhanced it further by revealing the Qur'an through it and by making it the language of the people of paradise. He relates a Hadith tradition of Prophet Muhammed stating the three reasons why people love the Arabs: Ana Arabiyu, wa'l Qur'an Arabiyu, wakalaamu Alu li janati Arabiyu (Manzur, 1992, p.7)

أنآعربي و القر آن عربي وكلآم أهل الجنة عربي

I am an Arab, the Qur'an is Arabic, and the language of paradise is Arabic. 
Similarly, Mahmud Taymur, a well-known Egyptian scholar and a member of Egyptian language academy, records that the Arabic language is the language of a revealed religion (Lughatu Dunn Samawiyyin) and that it is bound to remain a living language as long as the Qur'an and Islam exist. At this point, the question may be asked, why should the Arabic language be the language of the Islamic religion in different societies? The answer to this question is that, if Islam is a universal religion that accommodates all human beings, irrespective of tribe or race; the Muslims prefer the use of Arabic because it is the language of the Qur'an and is the basis to unify all Muslims (Johnson, 1921, p. 22).

However, prior to the emergence of Islam in Yoruba society, there was no specialized form of written culture. Only signs and symbols of art works were used to express desires and emotions, but only few people understood or attached significant meanings to them. In the nineteenth century when colonialism was imposed and Christianity was introduced, further confirmed the fact that the Christian missionaries, in their attempt to develop a standard Yoruba orthography, to enable them to undertake scholastic and evangelistic work considered, among other options, adapting the Arabic script. On this point, Samuel Johnson says:

The earliest attempt to reduce this tongue into writing was in the early forties of the last century when the church missionary society... organized a mission to the Yoruba country... After several years made either to invent new characters or adapt the Arabic which was already known to Moslem Yorubas, the Roman Character was naturally adopted (Malik, 1979, p. 10).

This shows that Arabic literary tradition has been in Yorubaland long before the advent of colonialism and Christian missionaries in the nineteenth century.

In recent times, there is a growing awareness of Muslim population using Arabic script to write their native languages. For instance, there are at present in northern Nigeria, publications in the Hausa language using the Arabic script. These include books, pamphlets and weekly newspapers. The current effort being made by the Morocco-based Islamic Educational Scientific and Cultural Organization (ISESCO), in encouraging the use of the Arabic script in writing the language of the Muslim peoples is noteworthy in this regard. Four Nigerian indigenous languages - Hausa, Kanuri, Fulfulde and Yoruba - are among the fifteen languages selected from East and West Africa by this organization which, in collaboration 
with the Islamic development bank, Jeddah (Saudi Arabia), has standardized the Arabic symbols and manufactured special typewriters for writing these selected languages. Three of such special typewriters are available in the Department of Arabic and Islamic Studies, University of Ibadan (Malik, 1979, p. 10).

According to S.H.A. Malik, empirical evidence shows that there are many people in Yoruba communities who cannot write English, French or Latin, but who can read and write things in their local languages using Arabic style. Thus, those who are erroneously considered illiterate are, in fact literate in Arabic (Mahmud, 1983, p. 37).

From the foregoing discussion, it is clear that the advent of Islam in Yoruba society is accompanied by the spread of literacy in Arabic, which provides a means of opening up communications in a way not possible for illiterate people. Hence, the Arabic language has played significant roles in providing a common form of literacy over large parts of Yoruba Muslims as well as establishing a means of both local and international communication. The society uses a caste or an occupational group whose members keeps records or preserves religions and moral precepts in written form or other specific purposes. Put differently, Arabic literary genre entails the degree of dissemination of Arabic knowledge among the Yoruba people imbibed with the skill of reading and writing Arabic (Malik, 1979, p. 10).

Arabic is inevitably interwoven with Islam. The intimate relationship between the two is reflected in the attributes and beliefs of the Arab and non-Arab Muslims over the centuries. They have always had great reference for the Qur'an, which exerted, from the outset, a great influence on their religious, political, social and intellectual life. For instance, it is compulsory that every Muslim must recite portions of the Qur'an in the Muslim daily prayers, no matter what the person's indigenous tongue may be (Malik, 1979, p. 10). This consequently enhanced the learning of Arabic both as an indigenous and foreign language in Yorubaland. In the early centuries of Islam in Yoruba communities, there were linguistic developments which stemmed directly from the religious stimulus and aesthetic appreciation of the Qur'an. In the long run, many non-Arabs were motivated to learn Arabic and suddenly the language found its users fast multiplying (Golden, 1968, p. 412).

The origin of Arabic literacy in Nigeria is dated back to the first appearance of Islam in Yoruba society around the eighteenth century. Since the introduction of 
Arabic literacy in Yorubaland, it has provided an important element of written communication of the Yoruba people, and it has served as an international language of West Africa in trade and commercial activities (Fajana, 1966, p. 11). Furthermore, knowledgeable Muslims in Arabic literacy provided useful service to the society as scribes and judges in the traditional political institutions of Ibadan, Oyo, Iwo and Ogbomoso civil service. The literacy capability made them the only ones capable of palace administration. The earliest of Yoruba literacy in Arabic was mostly based on poems and letters written to one another discussing religious problems in different parts of Yoruba society (Bidmos, 1972, p. 20). For example, Professor H.K. Bidmos mentions that Sheik Muhammad Belgore of Ilorin sent a poem to Sheik Abu Bakr, a Hausa scholar from northern Nigeria (Mahmud, 1983, p. 37). Also, another important poem was sent by Muhammed al Sanusi Ibn Harun, popularly known as Alfa Sanusi Khatibi to the Muslim community of Ologbowo quarter in Lagos after a religious/political crisis between Ibadan Muslims and the then Olubadan Dada (Martin, 1965, p. 20).

Another prominent Yoruba scholar in Arabic writing is Ahmed Abu Bakr (18701936) of Ilorin descent. He wrote one of the earliest prose works titled Ta'lif Akbar al qurun nun umara balad Ilorin in 1912. It is a history of Ilorin, which gives details of some information that is not found in other Western works. This important book has been discussed at length by Professor B.G. Martin (Mahmud, 1983, p. 37), formerly Head of the Department of Arabic Studies, University of Ibadan.

Also, Ahmad al-Rufai Ibn Bello (1886-1971) of Ibadan is a well-known Arabic writer. He wrote many poems and also compiled a history of Islam in Ibadan, titled Nubdha min tarajim Ajdad fil al Muslimin fi balad Ibadan. This work gives details of the ways Islam was resisted by the non-Muslims in Ibadan. This is Information which most modern Islamic scholars had ignored for a long time (Hunwick, 1997, p. 210).

According to J. Hunwick, the origin of Arabic writing in Nigeria dates back to over a period close to 800 years. He explains that the first known writer in Arabic was a grammarian and poet of Kanem Bornu Empire, Abu Ishaq Ibrahim El Kanemi. Arabic literary tradition started in Yorubaland since the 19th century, when Ilorin emerged as one of the major centres of Islamic teaching in Nigeria. Ilorin provided an effective bridge of Islamic learning between the centres of Hausaland and Bornu 
and developed new centres of Islamic learning in Yorubaland such as Ibadan, Ijebu Ode, Abeokuta and Lagos (Hunwick, 1997, p. 210).

More importantly, Hunwick mentions the role of two prominent Ilorin Islamic scholars who have been especially active in promoting the reading and writing of Arabic, not only within the city, but also widely in south-western Yoruba cities. Muhammed Juma Alabi, known as Taju al adab, founded a number of Arabic schools and his pupils have carried on the tradition to different areas in Yorubaland. Also, Sheik Adam Abdullahi Al-Ilory founded the Markaz Arabic College at Agege in Lagos in 1954 and later established a printing press where his voluminous writings on a wide variety of topics in Arabic (Parrinder, 1959, p. 130).

Arabic was the only written language known to the Yoruba people before the advent of Western education. Arabic literacy was a very prominent phenomenon among the Yoruba Muslim communities in south-western Nigeria by the beginning of the twentieth century. It has made outstanding literary contributions to the indigenous West African civilization by bringing the first form of literacy in Arabic to West Africa. Many West African languages, such as Wolof, Madimka, Hausa, Fulfulde and Yoruba were commonly written in Arabic (Carnoy, 1974, p. 25).

At this point, the rhetorical question may be asked, how has Islamic literacy affected Yoruba cultural heritage? Islamic literacy had greatly influenced Yoruba civilization in several ways. First and foremost, the Yoruba contact with Islam led to the rise of creating new medium of education within the Yoruba society. It's essential service is transmitting the knowledge and culture of Islam from one generation to another. It is a lifelong process of making the Yoruba people to undermine the local means of education and their religious belief system (Lasisi, 1995, p. 12).

Furthermore, Islamic education came to most countries of Africa and Yoruba land, in particular, as part of doctrinal domination. The cultural behaviour of the people has been changed due to the influence of Islam. The Muslim mallams have attempted, through Islamic education, to make the Yoruba people to perform roles suitable to Islamic ideologies (Crowther, 1968, p. 61).

The early Muslim preachers in Yoruba society looked down on the people as ignorant, superstitious and uncivilized. They considered them redeemable once they were Islamically educated and practiced the virtues of Islam. The presence of 
Islamic education has destabilized the Yoruba belief system and culture. Particularly in art, naming, education, language, values and norms, as well as religion (Willet, 1973, p. 34).

Before and under colonial rule, Islamic schools were organized for the purpose of teaching people how to read and write Arabic. Naturally, the school began with the education of the family members of the chief's compound (Baale) which gradually culminated into the conversion of the chief and members of the ruling elite in most Yoruba communities. The effect of this school system upon the people of Ibadan was traumatic. The group of educated Muslim children indiscriminately confronted the cultural and religious norms and values of the society. The Muslims, in their preaching, condemned the practice of wood sculpture of Yoruba deities enshrined in the belief system of the people (Nduka, 1980, p. 15).

Another major effect of Islamic education was that it led to a marked dislocation of the society and the neglect of the mainstay of the Yoruba economy. The attempt to redress this balance has been unsuccessful and the difficulties increase as the Yoruba society grows. A number of remote and immediate causes have been identified by scholars to explain this (Trimingham, 1969, p. 50). According to J.S Trimingham, at inception, the early Muslim preachers in Yoruba communities did place heavy demands for the complete abandonment of the Orisa religion. It was often emphasized in the early stage of Islam in Yoruba society that one can be a Muslim without understanding Arabic or other teachings of Islam. It is believed among the Muslims, that the simple affirmation that "There is no God but Allah, and Mohammed is the messenger of God" is sufficient for a person to be accepted into the fold of Islam. For this reason, many non-Muslims began to accept Islam because they wanted to be associated with a new and foreign religious ideology (Ayandele, 1992, p. 21).

According to E.A Ayandele, the Muslims did not attack or condemn polygamy even when it involved more than four wives, as prescribed by Islam (Ayandele, 1992, p. 21). For example, at Ijebu ode, Chief Kuku accepted Islam in 1902 for the main reason that Islam permitted the practice of marrying more than one wife. The Muslim preachers never condemned his action, even though he had more than four wives; rather he was encouraged to become a Muslim and persuade all his friends, wives and relations to join him in the fold. Consequently, many people began to accept Islam so as to associate with the elite, like Chief Kuku (Malik, 1999, p. 10). 


\section{Arabic literacy and its influence on Yoruba language}

As the teaching of Arabic language spread to different parts of Yorubaland, so was the influence of the Arabic language on the Muslims. The Arabic language had had a lasting impact on the linguistic life of Yoruba people. As Islam grew in many Yoruba towns, written and oral communication in Arabic became essential for the practice of Islamic culture. The spread of Islam came to involve the spread of literacy in Arabic for the easy understanding of the divine word of the Qur'an and the law which was based upon it (Lawuyi, 1995, p. 4).

Since the introduction of Islam into Yoruba society, it was closely associated with the activities of Muslim traders and the war championed by the Fulani Jihadists, which consequently resulted in the internal diffusion of the invaders, who spoke mainly Arabic to the Yoruba territory. Furthermore, long distance trade, particularly in primary items, such as salt, horses, kola-nuts, secondary products, such as clothes, beads and manufactured wares became the monopoly of the Muslim merchants, which they largely exchanged with the Yoruba traders (Mahmud, 1983, p. 37). Essentially, Arabic literacy was seen as a valuable asset for Yoruba traders to enjoy effective trading with the Hausa people. The advantage of using Arabic words among the Yoruba traders was very obvious. The fact that the traders from Hausa and Nupe descent could not communicate in any language other than Arabic, made the spread of Islam on a large scale possible. The Yoruba people were compelled to borrow some Arabic words from Islam for easy communication (Reichmuth, 1966 p. 15).

S. Reichmuth claims that Arabic is a symbol and expression of Islam as a unifying force for all Muslims in the world and that it is through this language that certain degree of cultural homogeneity has been achieved, through Islamic socialization. Examples of some of these loan words include: Adua (Prayer), Tuuba (Repent), Musiba (Misfortune), Wakati (Time/Hour), Alaafia (Good Health), Sababi (Cause) (Parrinder, 1959, p. 130).

Arabic as a language has been very influential in the Yoruba linguistic community; this is because it is a religious symbol and an expression of national identity of a powerful world religion (Islam). In other words, the Arabic language is influential because of the social importance that is being attached to it in the practice of Islamic religion, Islamic political system, Muslim laws and ritual worships. Also the Arabic language may be regarded as influential in the sense that it was the 
language that was used to promote and propagate Muslim influence to dominate or change the beliefs system of the non-Muslim to an Islamic one. This is shown in the language of Muslim elitist through their preaching in Yoruba society (Reichmuth, 1966 p. 15).

In Ibadan like in many other Yoruba towns, Arabic is the religious language used liturgically by the Muslim groups. It is used in Muslim supplications and in general mode of Islamic worship. The recitation of the Arabic Qur'an is often used to propagate the Muslim's faith and other religious formulae. Today, Arabic is studied in several schools and universities in Ibadan as a second and foreign language. It has been one of the greatest languages of civilization accompanying Islam across the world (Malik, 1979, p. 11). S.H.A Malik claims that the Arabic language is an important means of communication geared towards facilitating a perfect understanding of the religion of Islam as well as the meaningful performance and the cardinal practice of Islamic religion in areas such as Salat (ritual prayers) and Hajj (Holy pilgrimage). This has helped the Muslims in Ibadan to engage in a spiritual worship and guidance through the readings from the Holy Qur'an and other Arabic statements used during prayers (Clarke, 1982, p. 42).

Islam injected the culture and language of the Arabs into Yoruba society. The Arabic language was effectively imposed as the language of Islam on the Muslim. There was a remarkable degree of forced acculturation of Islamic belief system on the Yoruba people who embraced Islamic religion. The Muslims penetrated Yoruba society for the non-Muslims to accept Islam. The Muslim missionaries campaigned seriously against the traditional religion. Islam does not view traditional religion as a way of life. The Muslims see Islam as better than any other religion. The Muslims often demonstrate in their preaching that the traditional religion is uniformed and uncivilized in its approach to dealing with God the creator of the universe (Peel, 1978, p. 25).

\section{The influence of Islam on Yoruba religion}

Before the emergence of Islam in Yoruba society, the people regard their religion as a sacred aspect of culture that requires no controversy, competition or crusades of evangelization. There is a common believe in one supreme God who manifests His essence in variety of spirits and natural phenomena. God is worshiped through various orisa (dieties), who control these spirits and natural phenomena. Each individual family or state has its own orisa, which was once worshiped and 
pacified by all members of that lineage. Since the advent of Islam, many of these practices have faded. This attest to the point that Islam has strongly influenced the Yoruba religion in many ways. J.D.Y Peel argues that Islam was seen as a major threat to the already existing Orisa religion. The body of knowledge, beliefs and practices which Islam brought to Yoruba people in West Africa was considered irrelevant to the existing and generally accepted Yoruba views on religion (esin) among the people. Religious art works, which form part of the category of Yoruba education that produces wood and stone images to represent the religious deities, were condemned by the Muslim preachers (Willet, 1973, p. 34). This gradually led to the decline and lack of interest of the indigenous people practicing their orisa religion. In some cases, the Muslims went as far as destroying various art works, such as masks, costumes of egungun, image representations of divinities, so as to reduce the level of local participation in Yoruba religious activity (Onishi, 1999, p. 36).

Islam also introduced a new Islamic legal system, popularly known as sharia. The provision of the Islamic law was known to many people but it was selectively and sporadically applied by the Muslim teachers. Islam had a profound effect on the people in their approach to legal matters, in their society (NAI, Oyo Prov., 247/101). The Mallams in Lagos, Ibadan, and Abeoukuta advocated for a change in the structure of the native court system by petitioning the district officer to request for the appointment of a Muslim man educated in the Qur'an to be a leading member of the native court as judge (NAI, Oyo Prov., 247/101). For instance, in Ibadan, this was resisted by the Bale and traditional council with a counter petition to the district officer opposing the approval of a Muslim judge in the native court. The Olubadan and traditional council stressed, thus, in the following words:

We have to inform you that we do not agree with the requests of these Chief Mallams because (sic) as from time immemorial none of these Chief Mallams has ever been a member of native court in Ibadan, and as such we are not of the opinion that it should now be established. If this is conceded then it will be a precedent for other religionists for similar requests and as the Ibadan population is mainly Yoruba, it is proper to maintain that only Yoruba laws and customs be observed. Besides there are Mohammedan judges in all our courts, we believe this is a sufficient representation for our Mohammedan citizens (NAI, Oyo Prov., 247/101). 
The above statement in the petition in question clearly indicates that the Mallams in Ibadan were advocating for the introduction of Islamic law (Sharia) in the operation of the native court and this is in contrast to the traditional criminal justice system of Ibadan people. This point shows how indigenous traditional authorities resisted the introduction of Islamic legal system in Ibadan. This indicates that Ibadan people strongly opposed the influence of Islam on their traditional legal cultural identity. This fact illustrates the point that the appointment of a Muslim judge as a member of the native court in Ibadan would exert domineering influence of Islamic law on the legal facet of the Ibadan people's cultural heritage. The district officer rejected the request of the Mallams on the ground that nothing should be done on the matter until the reorganization of the native court. So should be kept in view for consideration. The acting resident of Oyo province agreed with the proposal of the district officer on the matter (Olupona, 1993, p. 12).

It must, however, be emphasized that the people have their own local ways of handling legal issues. Muslim teachers also engaged in polemical debates with traditional priests, diviners and their devotees. Popular songs and lyrics were composed to express the Muslim counter-positions to Orisa worship. For example, esu was portrayed as devil, whose house is a road junction and one who demands for the most prized possession of his clients for sacrifice (onile orita, Asotele apoti) (Olupona, 1993, p. 12). In the same vein, Ifa, a system of explanation, prediction and control, of space events, was particularly attacked with the words of abuse and insult to its worshippers, although Islam also deals with divination (Abdul, 1970, p. 56). M.O. Abdul rightly observes that, among the Yoruba Muslims, certain predictions about life troubles are carried out with the consultation of Muslim clerics by way of using Muslim rosaries (tasibih). Hidden facts about people who consult these clerics were revealed without any previous knowledge about the person who made such request. Hence, Islam also believes in divination (Ogunba, 1976, p. 215).

Another important area where Islam has affected the Yoruba religion is in the practice of traditional religious worship through music and dancing. The Yoruba are very lively people; they use music and dance to demonstrate their happiness, sincerity and devotion to their Orisa (deity) (NAI, Oyo Prov., File 1771). In most cases, annual religious festivals are boisterous; involving pageantry and formal patterns of dancing for the concerned priests and important chiefs (NAI, Oyo Prov., File 1771). 
For instance in Ibadan, Oke'badan festival is one of the most popular traditional feasts in the town from time immemorial. The Muslims in Ibadan wrote petition against its celebration in the twentieth century. In an extract from the minutes of the Ibadan Native administration general council meeting on the abolition of Oke'badan festival held on Monday, the 30th day of May, 1938 (NAI, Oyo Prov., File 1771). The resident officer categorically stated that two petitions were received from the leaders of the Christians and Muslims asking that the Oke'badan festival should be abolished and that the district officer subsequently replied that it was not a matter that the government could interfere. He maintained that people have the right to practice any religion of their choice. At the meeting, the Olubadan asked the resident officer why the petitioners called for the abolition of the Oke'badan festival and the resident officer replied that it was stated in their petition that the chief reason for the request for the abolition of the festival was that it was characterised by condemnable ritual of vulgar songs and obscene performances (Doi, 1969, p. 62). One obvious religious culture across most religions of the world is that each religion has a peculiar festival. However, the advent of western civilization in Ibadan led to the Christians and Muslims clamour for the abolition of Oke'badan festival which was a popular traditional religious feast in the town. The clamour for the abolition of Oke'badan festival by the Christians and Muslims of Ibadan in their petition shows how the adherents of these two religions defy religious precepts by condemning the oral tradition associated with Oke'badan as obscene and therefore could be interpreted as an unholy alliance against Yoruba feast in Ibadan (Qur'an, Ch. 31, V. 6).

This cultural practice has declined due to the influence of Islam. Muslim sects, such as the Bamidele and Lanase movement in Ibadan, condemned, in its entirety, the practice of dancing and listening to ritual music (Bukhari, Vol 7, 494). This is evident in Quran chapter 31 verse 6 when Allah states that:

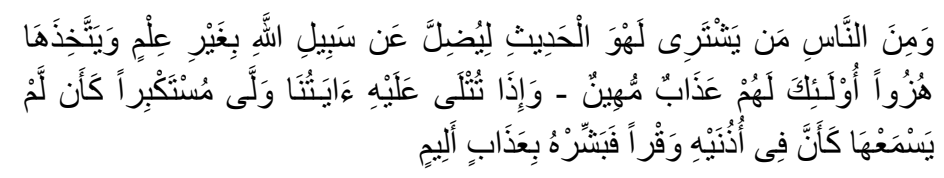

And of Mankind is he who purchases idle talks i.e. music, singing, etc to misled (men) from the path of Allah without knowledge and takes it (the path of Allah, or the verses of the Quran) by way of mockery. For such there will be humiliating torment in the hell fire (Majasan, 1967 p. 47). 
The above view confirms the point that music is characterized with idle talk or obscene language that are not acceptable or permissible in Islam. This is also corroborated with evidence from the traditions of Prophet Muhammad (PBOH) that Islam considers usage of musical instruments as illegal. Sahih Bukhari Vol. 7, Hadith number 494

Narrated by Abu 'Amir or Abu Malik Al-Ash'ari:

that he heard the Prophet saying, "From among my followers there will be some people who will consider illegal sexual intercourse, the wearing of silk, the drinking of alcoholic drinks and the use of musical instruments, as lawful. And there will be some people who will stay near the side of a mountain and in the evening their shepherd will come to them with their sheep and ask them for something, but they will say to him, 'Return to us tomorrow.' Allah will destroy them during the night and will let the mountain fall on them, and He will transform the rest of them into monkeys and pigs and they will remain so till the Day of Resurrection (Fajana, 1966, p. 11)."

However, the Muslims have their own music which is known to be devoid of obscene language idle talk or with usage of musical instruments. Music was also an important medium used by the Muslim preachers in Yoruba society to attract nonMuslims children in the town. Music is encouraged in Islam for women who are having their wedding celebration.

\section{The influence of Islam on Yoruba educational system}

Since the introduction of Islam to Yoruba society, the Yoruba system of education has declined. According to J.A. Majasan, Yoruba education is a process through which the Yoruba people seek to open their life to all members of the group and enable them to take part in it. Also, it attempts to pass on to the young Yoruba culture, including the standards by which society permits them to live (Majasan, 1967, p. 47). Yoruba education is a special body of knowledge that involves every individual in the society who are members of the community and not a privileged few as in Islamic education. Also, the word culture suggests that Yoruba education was not foreign. It has helped to improve the living standard of all individuals in the society, by providing rudimentary skills and knowledge necessary to interpret the universe of the Yoruba people. Yoruba education includes not only the art of 
making simple weapons and tools of simple technology, but also the myths, legends, folktales and taboos which instruct and regulate the mores of Yoruba people (Majasan, 1967, p. 47).

Islamic education was alien to the Yoruba people. Its education is geared towards reducing the practice of Yoruba art which is a major feature of Yoruba education. It makes it difficult to find outstanding craftsmen who are competent in carving and casting in the traditional style because the demand for their products has declined, due to the rejection of the practice, courtesy Islamic cultural influence through its education (Herskovits, 1973, p. 42).

Another major effect of Islamic education is the distortion of the practice of folklore education among the Yoruba people. J.A. Majasan describes folklore education among the Yoruba people as one of the most effective methods of instructing the young. It explains the common rules and the established etiquette of daily life (Oduyeye, 1982, p. 15). Every aspect of folk life is guided by a particular aspect of the folklore commenting on the educational use of folklore among the non-literate Yoruba people. Herskovits has this to say:

Folklore performs varied functions. Myths explain the universe. It provides a basis for ritual and belief. Tales which are customarily distinguished from myths because of their secular character are often regarded as an unwritten recording of tribal history. They act not only as a valuable educational device but are equally valuable in maintaining a sense of group unity and a group worth. Proverbs, which with riddles have essentially old word distributions, garmish conversations with pointed allusion, help clarify and obscure reference to one deficient in worldliness, and moralise. They may even as in Africa, be cited in courts of justice in the pleading of a case, just as legal precedents are introduced in our court of law. Riddles divert by serving as a test of wits; they give prestige to one who can "pull" with sureness and case (Oseni, 1981, p. 17).

From the above submission, we can deduce how folklore is an important feature of Yoruba educational system. But since the advent of Islamic education, folklore education has become unpopular and unappreciated by the people of Yoruba society because of the influence of Islamic learning. In the area of culture, Islam also had a profound effect on Yoruba culture. Culture, which is transmitted from 
one generation to generation, is an important element of Yoruba education (Oseni, 1981, p. 17). For instance, the Yoruba usually name their children after popular deities within the family, lineage or clan of the community. This practice which was common among the people for centuries is no longer fashionable. Many people do not name their children with names associated with deities. What is common now is giving of their children names that are well known among the Muslims (Willet, 1973, p. 34). Some examples of Yoruba names associated with religious deity and their meanings are highlighted below:

$\begin{array}{llll}\text { - } & \text { Ogundola } & - & \text { The god of Iron has provided } \\ \text { - } & \text { Fagbemi } & - & \text { The oracle has blessed } \\ \text { - } & \text { Fayemi } & - & \text { Ifa } \text { oracle blessed me } \\ \text { - } & \text { Orisabunmi } & - & \text { god gave me } \\ \text { - } & \text { Falase } & - & \text { The oracle has the final say }\end{array}$

These muslim names are mostly derived from the Holy Qur'an which is the revered book of guidance of the Muslim Ummah (community). Most Muslim names are drawn from the attributes of Allah (God) as contained in the Qur'an, and names of the prophets of Allah, pious and great men of Islam that lived during the time of prophet Muhammed. Examples of such names and their meaning are highlighted below under the three categories mentioned earlier:

\begin{tabular}{|l|l|l|l|}
\hline A & $\begin{array}{l}\text { Attributes } \\
\text { of Allah }\end{array}$ & Meaning & Muslim name \\
\hline 1 & Al-Hakim & The wise Lord & $\begin{array}{l}\text { Abdul hakeem servant of the wise } \\
\text { Lord }\end{array}$ \\
\hline 2 & Al-Rahman & The blessed Lord & $\begin{array}{l}\text { Abdul Rahman servant of the blessed } \\
\text { Lord }\end{array}$ \\
\hline 3 & Al-Gafar & The forgiving Lord & $\begin{array}{l}\text { Abdul Gafari servant of the forgiving } \\
\text { Lord }\end{array}$ \\
\hline
\end{tabular}

Names of some of the prophets of Allah that are well known among Yoruba Muslims include: Musa, Muhammed, Hisa, Yahaya, Yusuf, Yunus, Zakarriyyah, Dauda, Sulaiman, Yaqub, Isiaka, Ibrahim, Nuha, Ayuba, Harun, Ilyas, and Ismaila. These names are common in the Muslim-dominated areas. Names of some pious and great men of Islam who lived during the time of Prophet Muhammed are as 
follows: Abubakri, Muslim, Thrimidh, Umar, Hanafi, Habiba, and Fatima, Ali, and Uthman among others (Carnoy, 1974, p. 25).

Frank Willet observes that Islam affected the growth of Yoruba artistic tradition. Islam discouraged the representation of living creatures and encouraged elaborate ornamental designs. These designs were mostly made on wood with Arabic inscriptions on doorposts, household objects and furniture. Thus, Islam has obliterated representational art of the Yoruba people, replacing it with Islamic artistic tradition. More importantly, Muslims rejected in totality the artistic representation of various Yoruba sculptures of living creatures that are found among the Yoruba in Ibadan. In fact, Muslims burnt several of these sculptures, such as Ere-Ibeji, Esu, Obatala, Sango, and Oya images on stone carvings (Fajana, 1966, p. 42).

M. Carnoy describes Islamic education as a lifelong process of educational teaching of the young and the old to understand important phenomena of Islam. It is a process of providing skills necessary for preparing the young and old for religious proselytization. The traditional theory of Islamic education is anchored on the premise that Islamic education brought the Yoruba out of their ignorance and underdevelopment into a condition of enlightenment and civilization (Elliot, 1948, p. 25).

However, the truth is that the Yoruba people had developed their own form of enlightenment and civilization even before the advent of Islamic education (Malinowski, 1936, p. 15). T.S. Elliot claims that the Yoruba have succeeded in educating the young population, by passing on to individuals the culture of the people and standard by which people could operate in the society (Oladosu, 2005, p. 32). Based on the views of B. Malinowski, the Yoruba child relies on the social and cultural milieu of the people, manifested in their family life, kinship structure and in the special setting of economic pursuit. This shows the degree or level of enlightenment and civilization in Yorubaland prior to the advent of Islam (Lawal, 2010, Interview).

A. Oladosu avers that Islam has affected the cultural behaviour of the Yoruba people of Ibadan, most especially in their burial tradition, marriage and worship of the divine being. Before the incursion of Islam in Yoruba society, Ibadan, like all other Yoruba towns, usually buried their dead ones inside the house in their family compound, but Muslims condemned this practice and persuaded the people to bury 
their dead ones outside their compounds (Saliu, 2010, Interview). This was also introduced by the Christians who even introduced buring the dead ones in the remote areas far from their family compounds. This point has been well articulated in the Yoruba proverb that states that: "Onifa sunle, Imale sunta, inu Igboni Igbagbosun, (the Ifa worshipper is buried in the house, the dead Muslim is buried outside the house, while the dead Christian is buried in the bush) (Fadipe, 1970, p. 264)

In the case of marriage, Islam frowns at collecting bride price. This is unlike the traditional Yoruba practice of payment of bride price by the family of the husband. However, Islam permits the collection of mahr (dowry) the wife alone and that no other person must have a share of the dowry even though they are the parents, relatives or siblings of the woman that is being given out for marriage. But, marital processes such as offer and acceptance of intending couples seeking the permission of both parents, avoidance of pre-marital sex and sexual interaction after marriage are similar practices in Islam and Yoruba traditional religion (Simpson, 1980, p. 15).

In the area of divine worship, Islam influenced the method of divine worship to the Supreme Being. Before the incursion of Islam into Yoruba society, the people approached Olodumare through a panoply of divinities known as Orisa. These Orisas are regarded as the patrons and guardians of the Yoruba communities. However, this practice changed to a greater extent due to the influence of Islam. Muslim preachers made many Yoruba people to dissociate themselves from the worship of Orisa encouraging them to believe in Allah and Muhammed (SAW), the messenger of Allah, perform Muslim ritual five daily prayers, give alms to the poor and visiting the Holy land of Mecca and Medina at least once in a life time. Thus, in the area of divine worship, Islam has greatly affected the Yoruba religious worship (Fadipe, 1970, p. 264).

\section{Conclusion}

This paper has investigated how Islam, through its education has influenced Yoruba cultural heritage in southwest Nigeria. The time frame for the study 19301987 highlights the cultural invasion of Islam during the colonial period when Muslims were allowed to maintain physical and cultural presence in Yoruba towns and 1987 when Islamic learning centres became well entrenched to promote Islamic civilization in the community. The powerful influence of Islam have affected the Yoruba cultural heritage in the area of religion, education and 
language. The paper has demonstrated that Muslim clerics from Hausa and Nupe parts of Nigeria established mosques and schools in several parts of Yorubaland to promote Arabic and Islamic civilization. It has also been observed from this study that Islamic literacy was mainly responsible for the spread of Islamic culture and erosion of Yoruba belief system. The ideal character which the Muslim teachers strove to teach in the Arabic schools was that of the Muslim citizen. The Islamic education was Muslim's cultural belief as exemplified in Islamic religion. The practical strategy adopted to achieve the aims of this education was not only by explicit moral and religious instruction, but also by practical examples of performing Muslim ablution and ritual prayers, salat.

The fact is that if urgent and serious measures are not taken to promote the interest and study of Yoruba religion, the religion will be extinct among world religions in the nearest future. Thus, the central theme of this paper points to the fact that Muslim system of education displaced the Yoruba system of education, religion and culture just as Western education was used by Christian missionaries to convert Muslims to Christians in the colonial period.

\section{References and notes:}

Abdul, M.O. (1970). "Yoruba Divination and Islam", Orita vol. 4, No. 1.

Ajayi, J.F.A. (1965). Christian missions and the making of Nigeria, 1841-1891. London: Longman.

Akinola, G. A. (1995). The Arabs in Africa: Reflection of a Forgotten Imperialism, Journal of Historical Society of Nigeria. Vol. xii, No.1 and 2. Pp. 1-28.

Ayandele, E. A. (1992). The Ijebu of Yorubaland: Politics, Economy and Society, Ibadan: Heinemann Educational Books.

Bidmos, H.K. (1972), “A Literary Appraisal of the Writings of the Yoruba Ulama”, M.A. Dissertation Department of Arabic and Islamic Studies, University of Ibadan. Chapter two.

Brown, G.N. (1975) "Introduction of Islamic Education" In Conflict and Harmony in Education in Tropical Africa, ed. G.N. Brown et. al. London: George Allen Unwin. 1975, pp. 91-92.

Carnoy, M. (1974), Education as cultural imperialism. New York: David Mckay Company. Clarke, P.B. (1982), West Africa and Islam: study of religious development from the 8th20th Century. London: Edward Arnold.

Crowther, M. (1968) West Africa Under Colonial Rule, London: Hutchinson \& Company.

Doi, A.I (1969) "The Bamidele Movement in Yorubaland" Orita: Ibadan Journal of Religious Studies. Vol. 5, No 1.

Elliot, T.S. (1948), Notes towards the definition of culture, in The Church Survey their task. London. Faber. Pp. 25 - 30. 
Fadipe, N.A. (1970), Sociology of the Yoruba. Ibadan: Ibadan University Press. Pp. 264 287.

Fafunwa, A.B. (1974), History of education in Nigeria. Ibadan: NPS Educational Publishers. Pp. $42-66$.

Fajana, A. (1966), "Some Aspects of Yoruba Traditional Education", Odu Journal of West African Studies. Vol. 3, No. 1.

Fajana, A. (1978) Education in Nigeria, 1842-1939. A Historical Analysis. Longman: Publishers.

Gbadamosi, T.G.O. The Growth of Islam Among the Yoruba, 1804-1908, London. Longman 1978. Pp. 77-93.

Golden, H.H. (1968), "Literacy", in Encyclopedia of the Social Sciences, ed.) D.L. Sills Vol. 9, United States of America; The Macmillan Inco. p. 412.

Herskovits, M.J (1973) Man and his Works. New York: A. Knopf.

Hitti, P.K. (1982) “Arab Civilization” in B.S. Gayne (ed.) The Encyclopedia American Vol.

2, New York, Americana Corporation, p. 112.

Holy Qur'an: chapter31 verse 6

Hunwick, J. (1997) "The Arabic Literary Tradition of Nigeria", Research in African Literatures, Vol. 28, No. 3, (Fall): 210-223. Database on-line. Available from Ovid, Periodical Abstracts Research II, PAR, Accession No. 03388544.

Johnson, S. (1921), The History of the Yorubas from the Earliest Times to the Beginning of the British Protectorates, Lagos, C.M.S. p. xxii.

Lasisi, R.O. (1995), "French Colonialism and Islamic Education in West Africa, 19001939”, Muslim Education Quarterly. Vol. 12, No 3. Pp. 12 - 22.

Last, D.M. (1967), The Sokoto Caliphate. London: Longman.

Lawal, Oladimeji (2010). Interview on the 28th of September.

Lawuyi, O.B (1995) "Islam, Economy and political identity: An insight into Yoruba religious identifications of the Yoruba". Ife: annals of the institute of cultural studies. No 6. pp. 4 - 15.

Mahmud, K. (1983) "The Arabic Literary Tradition in Nigeria", Nigeria Magazine, No. 145 , pp. 37-54.

Majasan, J.A. (1967) "Yoruba Education: Its Principles and Practice", Department of Adult Education University of Ibadan.

Malik, S.H.A. (1979) “Arabic, The Muslim Prayer and Beyond” Inaugural Lecture, Ibadan: Ibadan University Press. pp. 10-11.

Malinowski, B. (1936), "Native Education and Culture Contact", International Review of Missions. XXV, October. Pp. $15-16$.

Manzur, M.I. (1992) Lisan al-Arab, Vol. 1, Beirut Dar Bayruit, p. 7.

Martin, B.G. (1965), A new Arabic History of Ilorin in Centre for Arabic Documentation (CaD) Research Bulletin, Vol. 1, No. 2, January, pp. 20-27. 
NAI, Oyo Prof. 247/101. Petition Report from the Olubadan-in-Council and his Chiefs against the appointment of Muslims Judges in Ibadan native court and petition report on Mallam's of Ibadan and Students to the honourable residents of Oyo. 1938.

NAI, Oyo Province File1771. Petition on Native Festival of Oyo Province Oke‘badan Festival.

Nduka, O. (1980), "Moral Education in the Changing Traditional Societies of Sub-Saharan Africa", International Review of Education. Vol. 26, No. 2.

Oduyoye, M (1982) Yoruba Names: Their Structures and their Meanings. Ibadan,. Daystar Press.

Ogunba, O. (1976) “ceremonies” in S.O Biobaku (ed.) Sources of Yoruba History. Oxford: Oxford University Press.

Oladosu, A. (2005) "Cross-Culturalism: Rereading Arabic into the African culture", in S.A Ajayi (ed.) African Culture and Civilization Ibadan: Atlantis Books. Pp. 32 - 64 .

Olupona, J.K. (1993) "The Study of Yoruba Religious Tradition in Historical Perspective", Numen vol. 40, Fasc No 3.

Onishi, N. (1999) "A Nigerian State turns to the Koran for Law". The New York Times 8, December.

Oseni, Z.I (1981). A Guide to Muslim Names. Lagos: Islamic Publication Bureau.

Parrinder, E.G. (1959)“Islam and West African indigenous Religion”. Numen, Vol. 6, Fasc 2, pp. 130-141

Peel, J.D.Y. (1978), “Olaju: A Yoruba Concept of Development”, Journal of Development Studies. Vol. 14, No 2.

Raheemson, M.O. (1988) The Rise and Growth of Islam in Ibadan, in G.O. Ogunremi, (ed). A Historical, Cultural and Socio-Economic Study of African City, Ibadan: Oluyole Club.

Reichmuth, S. (1996) "Education and the Growth of Religious Associations Among Yoruba Muslims: The Ansar-ud-deen Society of Nigeria", Journal of Religion in Africa Vol. 26, Fasc. 4.

Sahih Bukhari Vol 7, Hadith 494.

Saliu, Ameen (2010), Interview on the 29th of September.

Simpson, G.E. (1980), Yoruba Religion and Medicine in Ibadan: Ibadan. Ibadan University Press. Pp. $15-17$.

Smith, H.F.C. (1961), "The Islamic Revolutions of the nineteenth century" Journal of Historical Society of Nigeria. Vol 2 No. 2.

Trimingham, J. S. (1969), History of Islam in West Africa Oxford: Oxford University Press. p. 62 .

Willet, F. (1973) African Art: An Introduction. London: Thames and Hudson. 


\title{
Summary
}

\section{Reconsidering the influence of Islam on Yoruba cultural heritage, 1930-1987}

\author{
Akeem Abiodun Oladiti \\ Ladoke Akintola University of Technology, Nigeria.
}

Previous studies on the activities of Islam have focused on the contribution of the religion to state building (Last, 1967, p. 4 ), the nineteenth century jihad (Smith, 1961, p. 45) and the phenomenal growth of Islam during the colonial period (Gbadamosi, 1978, p. 77). However, no specific attention has been paid to how Islam affected Yoruba culture negatively with specific focus on the area of religion education and language. This study intends to fill this obvious gap in the historiography of influential cultural invasion of Islam from 1930, when colonial political structures allowed the Muslims to maintain a physical and cultural presence in Yoruba towns to 1987 when the proliferation of Islamic learning centres became well established to promote Islamic cultural orientation in the community.

primary data on colonial petition reports were sourced from archival materials as well as oral interviews with people selected through purposive sampling technique while the secondary data were derived from books and journal articles. The data collected through these methods were classified and subjected to qualitative analysis. Arabic schools throughout Yoruba land were established as centers promoting Arabic civilization and Islamic cultures (Bidmos, 1972, p. 32). These schools were found in most of the large urban cities in Yoruba city states such as Lagos, Ibadan, Ilorin, Abeokuta, Saki, Osogbo, Ede and Ikirun (Mahmud, 1983, p. 37).

The activities of these schools were geared towards producing Yoruba Arabs. These schools encouraged the wearing of turban (al-hammamah), the flowing robe (jalamiyyah and hijab). Arabic words with lexical equivalents in Yoruba lexicography. Some Muslim scholars that graduated from these Arabic schools branded their physical appearance by keeping long beards as a measure of cultural affinity with the Arab Muslims. The influence of Islamic literacy has also manifested in the mode of naming such that converts changed their names deemed associated with Yoruba deities to Islamic names. There were also reports of instances Muslim clerics spearheaded and attacked Yoruba religion, language and education. Islamic literacy has brought about cultural changes in the mode of language, beliefs and education of the Muslims in Yoruba society. The Arabic schools in Yoruba society promoted cultural influence with the establishment of structures which undermined the preservation of Yoruba religion, language and education.

Keywords: Islam, Yoruba, culture, Muslim, Jihad 